\title{
8. Cap Bocage Tracing the militant voice of environmental protest in New Caledonia
}

\begin{abstract}
This article is an attempt to document some of the filmmaking processes and highlight some of the specific factors that determined the final form of the film Cap Bocage. I see this as an opportunity to outline more personal reflections on process. This article will firstly give context to some of the filmmaking challenges by discussing the idea of the voice of a documentary (Nichols, 2010, p. 256) as it relates to subject matter. Here I will emphasise the idea of a personal approach to story that sometimes runs adjacent to the traditional techniques one may find in more expositional work or in a purely journalistic rendering of the narrative. This article also explores two other works that concern themselves with militant struggle in New Caledonia. One is the feature length drama Rebellion (Kassowitz, 2011) and the other a documentary: Tjibaou le pardon (Dagneau, 2006). While the approach to the history of militancy in the films is different, both works are good examples of the challenges filmmakers face while tracing stories involving conflict or societal trauma.
\end{abstract}

Keywords: conflict, documentary, environment, mining, New Caledonia, New Zealand, protest, trauma

\section{JIM MARBROOK \\ Auckland University of Technology}

\section{Introduction}

N 2014, I produced Cap Bocage, a documentary focusing on Florent Eurisouké and his battle to clean up a landslide, from 2008, at a mine near his home tribe of

$\mathrm{Ba} /$ Kaora. The tribe of $\mathrm{Ba} / \mathrm{Kaora}$ is in the Houailou area on the east coast of New Caledonia's main island. The landslide occurred after substandard mining practice caused a hillside to collapse, and 20,000 tonnes of nickel and cobalt enriched ore were spilt onto tribal fishing grounds on the reef below. The fear among locals was that marine life would be poisoned and fishing grounds would not recover.

The protracted clean-up process focused attention not only on the stewardship of the mine but also on wider questions that surrounded the legitimacy of mining exploitation in the Houailou area. The conflict was also specifically local. An environmental association, Mèè Rhaari, was formed to challenge the local mining company who held the mining license. La Société des Mines de Cap Bocage have been exploiting the mine 


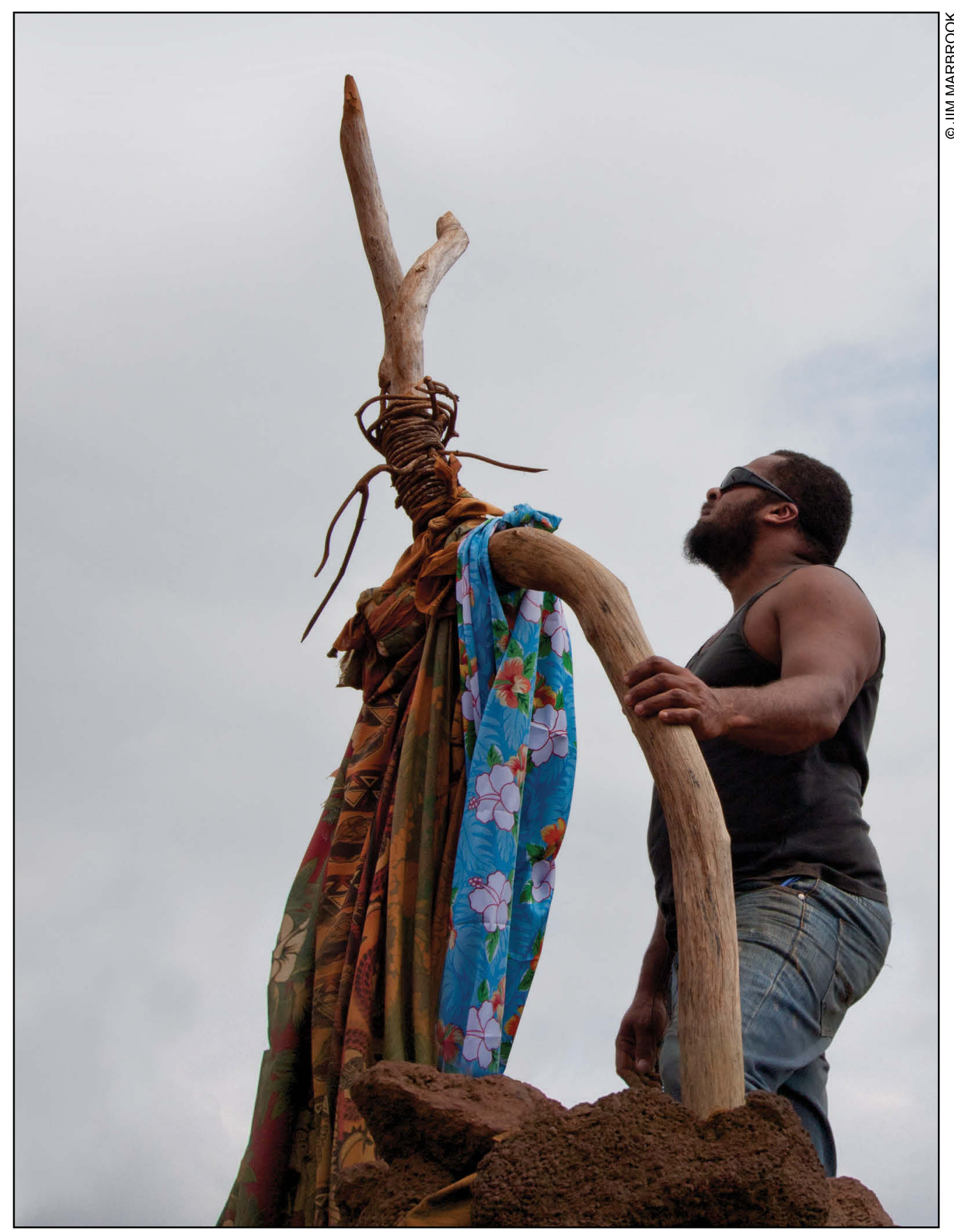

Figure 1. Florent Eurisouké in a still from Jim Marbrook's 2014 documentary Cap Bocage.

PACIFIC JOURNALISM REVIEW 21 (1) 2015111 
since the early 1970s and are owned by the Ballande group, a business set up by one of the first white settler families to set down roots in the territory. Despite the specific local nature of the conflict, protests and opposition to the company can be linked to wider dissatisfactions within Kanak communities across the territory.

While the timeline of the clean-up, the protests, and the court cases that followed the landslide, form the backbone of the story, my own interest was in Florent himself. In 2008 he was a young activist (in his thirties) in the process of negotiating his way through a complex and ever-evolving landscape of protest and confrontation (Figure 1).

From the first day of the shoot, it was obvious that Florent was a controversial figure. He is militant, charismatic (sometimes divisive) but is also a man who appeared to have a natural confidence and ease in public forums and debates. Our initial footage documented a meeting and dispute on barricades that had been set up to block the mine. From the outset it seemed the strongest thread to the story would be Florent's journey through the complex va et vient of protests and negotiations. In essence, I hoped, the film would give me the opportunity to track the political and personal trajectory of a young militant. The challenges in telling such a story not only involved acquiring a cultural and historical framework of the area but also involved invoking a specific filmmaking approach that cohered with the presentation of Florent's personal story. Here, finding the balance between elements that were necessary for the exposition of the action, and then matching these with a more intimate focus on an individual, would become the biggest filmmaking challenge.

This article is an attempt to document some of the filmmaking processes and highlight some of the specific factors that determined the final form of the film. I see this as an opportunity to outline more personal reflections on process. This article will firstly give context to some of the filmmaking challenges by discussing the idea of the voice of a documentary (Nichols, 2010, p. 256) as it relates to subject matter. Here I will emphasise the idea of a personal approach to story that sometimes runs adjacent to the traditional techniques one may find in more expositional work or in a purely journalistic rendering of the narrative.

Secondly, I want to consider two other works that concern themselves with militant struggle in New Caledonia. One is the feature length drama Rebellion (Kassowitz, 2011) and the other a documentary: Tjibaou le pardon (Dagneau, 2006). While the approach to the history of militancy in the films is different, both works are good examples of the challenges filmmakers face while tracing stories involving conflict or societal trauma.

Further to this, I will discuss two scenes from the film that speak to the idea of documentary voice, and highlight some of the filmmaking choices that shaped the scenes themselves. Here, I will integrate some of Michel Naepels's (2013) recent academic work as it relates to the cultural context and social background of the Houailou area. Situating the ideas that surface in Cap Bocage alongside this research will not only give some context to the impact of colonisation as it relates to cultural structure, but also to

112 PACIFIC JOURNALISM REVIEW 21(1) 2015 
the wider search for legitimacy environmental protest groups must secure if they are to successfully challenge corporate structures (Horowitz, 2008).

Finally, I want to reflect on the current situation in the territory and include some thoughts on the recent negotiations between the tribe at Ba/Kaora and Ballande. Florent's position remains firmly against any mining development and, in the eyes of many, he is perceived as inflexible. But understanding his position can also help us locate the increasingly subtle neoliberal strategies mining companies use as they capture and co-opt support (Horowitz, 2014) and reframe future activities that may have uncertain and unresolvable environmental consequences.

\section{Establishing 'the voice' of Cap Bocage}

Documentary theorist Bill Nichols maintains that one of the key differences between fiction and documentary concerns the rhetorical position the filmmaker takes with regards to the subject of the film. While he identifies a series of documentary storytelling modes to better identify techniques and approaches that highlight the filmmaker's position as storyteller, he sees the idea of the documentary maker's 'voice' as being the key to understanding documentary process and point of view. He identifies voice as 'something narrower than style: that which conveys to us a sense of the text's social point of view, of how it is speaking to us and how it is organising the materials presented to us' (Nichols, 2010, p. 259).

In relating these ideas to my own practice, one of my major concerns is providing the structure whereby the positions of the main participants are conveyed in a manner that is the most direct and unmediated. My feature-length documentary work has purposefully excluded any omniscient narration. In Dark Horse (2003) this involved focusing on one central character, a Māori speed chess maestro, and his experiences and ideas drove the story. In Mental Notes (2012), the structure of the film coalesced around the stories of ex-mental health patients and a thematic progression of ideas served to guide the story rather than any reliance on a commentary track. Again, the concern was to frame personal stories in the most direct manner and to allow an audience to come as close as possible to the documentary subjects with minimum intervention by the filmmaker.

In a way, these ideas and approaches were the 'baggage' I carried into the production of Cap Bocage. But as I began examining the media landscape in New Caledonia, it became obvious that ideas of documentary were bound up in reportage-style of television documentary, which has its roots in mainstream current affairs pieces transmitted on French television. The idea of continuing this more direct and unmediated approach to the filmmaking process also seemed the best way of providing New Caledonian audiences with a different way of interpreting issues. My initial trip to the territory in 2007 was as the Pacific Media Centre's Journalist-in-Residence. The idea of the trip was to encounter and interview some of the radical voices from the eighties. This period of New Caledonian history was a time of protest and near-civil war, and is now simply referred 
to as les événements. Some of these interviews were filmed but the most interesting were informal 'off the record' conversations.

Many of the radical voices from les événements now had political careers, and their current concerns mostly involved maintaining a coherent and effective political force that could realistically challenge parties not supporting moves for an independent Kanaky. The radical positioning of the eighties seemed to have been subsumed by a pragmatic realpolitik. The future independence of the territory will be decided in 2018 with a referendum (or a series of referenda), and the political landscape seems to dictate that only a level-headed approach to the idea of an independent Kanaky will convince an increasingly evolving electorate of its viability. New Caledonia also receives substantial monetary transfers from metropolitan France. A loss of this financial security would mean the future wealth of the country is even more inextricably linked to revenue from nickel and cobalt mining. This complicates the relationship between politics and mining.

When I returned to the territory in 2008 to film protests against Vale NC's huge mining development at Goro (at this stage owned by Inco and called Goro Nickel), the protest group, Rhèèbu Nùu, was headed by Raphael Mapou, an ex-politician. Their fight was an on-the-ground campaign of direct action that was paralleled by a legal battle against the mining company. This legal battle was guided by a French lawyer who specialised in indigenous rights. The complicated nature of this industrial project has been previously discussed in Pacific Journalism Review (Gooch, 2015) and the legitimacy of the protest movement, its place within the local clan and tribal structure, has been comprehensively analysed by Leah Horowitz (2008). My initial interviews with Mapou and later interviews with Jerome Bouquet-Elkaim (Rhèèbu Nùu's lawyer) in France revealed a sophisticated campaign that was slowly beginning to target overseas shareholders. It was publicity savvy and self-aware.

In April 2008, I filmed a rally on Ile Ouen: the centre of protests that began ramping up in response to the work that had started on a huge outfall pipe from an in-construction nickel processing plant. The pipe would dump diluted effluent into the lagoon. The fact that the pipeline was an obvious and tangible incursion into a zone that would become a Unesco World Heritage site had not only incensed Kanak tribes but had also affected New Caledonians of European heritage. My interviews with Kanaks during these island protests revealed a massive groundswell of discontent about the mining development and its consequences. Future acid spills and a broken effluent pipe would eventually validate these fears.

I began collaborating with French filmmaker Clarisse Feletin on a longer work that would cover this story. The structure of such a piece would require a filmmaking approach that needed to be able to explain nickel processing techniques, the history of the protest, contain a clear analysis of the local and off-shore politics of the mine and also reference the cultural and social dynamics of the situation. It was an approach that needed a more journalistic style to process and contextualise information. The two leaders of Rhèèbu Nùu,

114 PACIFIC JOURNALISM REVIEW 21(1) 2015 
Raphael Mapou and Andre Vama, had taken public political roles in the fight against the mining company and their more public roles in the conflict also indicated that a personal approach to the story would be more problematic to film.

During the mounting protests in the south, I went to north to Houaliou and shot the first stages of the Cap Bocage protests. While Goro was grabbing headlines, there were elements to the story at Houailou that were more compelling to me as a filmmaker. Unlike the situation in the south, where protests began moving into lawyers' offices, the events in Houailou were evolving in real time. This offered opportunities to employ a greater variety of filmmaking options, including searching for ways to meld interviews within the observational treatment of actuality. Again, the intention was to move away from current affairs-style coverage.

Finding the 'voice' of the documentary also involved other considerations. Tracing the form of recent documentaries in New Caledonia, as mentioned, means untangling a mode of address that seeks to unpackage facts, events and ideas, and is dominated by the reportage-style approach. But the treatment of the radical voice in the New Caledonian film can also be illustrated by two interesting recent works which look at similar issues. One film was centred on the 1988 crisis on the island of Ouvéa when gendarmes were held hostage by Kanak radicals. Subsequently, the hostage-takers were killed by military forces. It is claimed that many of the Kanaks were killed after they had surrendered. The second film was based on the contemporary trauma associated with FLNKS leader JeanMarie Tjibaou's assassination, on the island itself, one year after the Ouvéa murders.

\section{Rebellion and Tjibaou Le Pardon}

The Ouvéa crisis was the key element that prefigured the Matignon Accords, the agreement that brought the FLNKS leader Jean-Marie Tjibaou and Jacques Lafleur to the bargaining table with Prime Minister Michel Rocard. The agreement that was forged sought consent and dialogue and tracked a pathway to autonomy. Tjibaou's subsequent assassination by Ouvéan FLNKS leader Djubelly Wéa has been interpreted as a reaction to both Matignon and to the reluctance of FLNKS leadership to follow through on the initial hostage situation with similar militant actions around the territory. The circumstances surrounding Ouvéa and the aftermath of the massacre express some of the societal schisms that an armed struggle can provoke but also the way that trauma must be dealt with, both by specific communities and also, collectively, as a nation.

Mathieu Kassowitz's drama Rebellion (2011) explores the Ouvéa massacre and the political intrigue that surrounded the case. Another film, the documentary Tjibaou le pardon (Dagneau, 2006), covers the aftermath and the attempts by Wéa's clan to redirect the shame and stigma of the event by a customary healing process involving the Tjibaou clan. The documentary, an RFO/ADCK (the cultural organisation with strong links to the Tjibaou legacy) production, is a Kanak-based view of the crisis guided by a Kanak narrator. Kassowitz's film focuses on Philippe Legorjus, the man who headed the elite 


\section{DOCUMENTARY PRACTICE IN THE ASIA-PACIFIC}

GIGN team, which was charged with negotiating an end to the stand-off and bringing out the police hostages. Kassowitz's version of the story is almost exclusively seen through the eyes of Legorjus, and the story zig zags between tension-filled moments on Ouvéa and scenes that portray a calculated military campaign that framed a political stand-off simultaneously playing out in France. This was the public sparring match between François Mitterrand and Jacques Chirac during the fight for the Presidency.

Reviewing the startling archival footage from the debates leading up to the final round of the election (France 2, 2008) allows one to understand the political tension underpinning the events in the film. Chirac, in hawkish mood, marginalises and minimises the role of the FLNKS in any political future of the territory. In this debate, he closes off any possibility of negotiation with them by branding Tjibaou as a 'terrorist' and negating any political support he may have by citing, as proof, the results of the last election, one which the FLNKS and its supporters boycotted. Mitterrand, by contrast, stresses the importance of dialogue and presents himself in the role of arbiter. The eventual Socialist victory paved the way for the tense negotiations at Matignon (pers. interview: Rocard, 2009) and the final agreement that led to the Noumea Accords ten years later.

In retelling the Ouvéa story, Kassowitz positions himself firmly against the Caldoche (white settler) version of the narrative and this, among other things, led the film to be boycotted by all cinemas in the territory. Le Figaro roundly criticised it and led their story with the headline 'The lies of Mathieu Kassowitz' [my translation] (Deransart, 2011).

The ten-year preproduction history of the film is an indicator of some of the difficulties that Kassowitz must have faced. The most overt of these was the customary decision not to grant access for Kassowitz's team to film in Ouvéa (French Polynesia eventually became the substitute location). While it is difficult to delineate all the reasons for this refusal, one can reflect on the complex nature of the customary decision-making process that must have led to it. Firstly, a wide range of voices on the island needed to be consulted. These were not only the specific tribes and clans directly involved in the hostage-taking but other tribes (each with their own specific clan structure) who were not directly involved in the event. Refusal of consent does not necessarily indicate unwillingness for the project to be made, but I believe it is a reflection of the fact that this decision-making process is complex and must go through customary channels as it involves wider Ouvéan society.

Kassowitz's proposition to film on the island, in essence, was a request to import a dramatisation of a past societal trauma back into Ouvéan society. In a wider sense it also sought to involve Ouvéans in the reintroduction, in a very public fashion, of ideas of conflict and (as the English film title references) rebellion.

As both Kanak and Caldoche factions are now involved in the end game, which will lead to the referendum for independence in 2018, the sensitivities of this process risk being enflamed by a work that revises and refocuses acts of militancy and one that also links these acts to French political decisions. Le Figaro's criticism involves not only the character assassination of the GIGN agent the book was based on (2011) but it negates

116 PACIFIC JOURNALISM REVIEW 21(1) 2015 
any historical analysis of issues that are furnished by les zoreilles (literally: 'the ears' - the recent arrivals from France). Kassowitz is firmly placed among those who have pressed le 'bouton canaque' and who have succumbed and been seduced with:

...Melanesian culture that attaches itself to the young, freshly-arrived little Frenchman from metropolitan France...impressed by these native languages where the verb 'to have' is non-existent, these tribes where one is possessed collectively by the bounteous earth, and where the respect of the customary leaders is sacred and determines a collective life where original communism can flourish. [My translation] (Denserat, 2011)

Such is the tenor of Le Figaro's piece. It consigns Kassowitz to the role of a misguided outsider who can never understand the reality of life on 'le Caillou' (New Caledonia, literally, the rock) as he, like many others, is 'fresh off the boat'. The review also, in asserting its own verity, comprehensively excludes any possibility that a traditional Kanak conception of society or culture can be relevant, its roots lying in a communistic system of values from which progress will never be made.

What we can see in this critique can be related to a wider societal attitude across a range of Caldoche voices. The revisionism (or reversionism) that was so offensive for Caldoches in Kassowitz's film was twofold. Firstly, it re-exposed New Caledonia's recent history to scrutiny and thus requestioned the motives and actions surrounding events that were essentially military assassinations (and, by extension, the validity of the Caldoche position vis à vis independence). Secondly, though, it focused on a part of history that forced an audience to reconsider militant reactions to oppression and colonialism. We see this fear clearly played out in the article as the author dismembers Kanak support for the FLNKS by minimising the popular support for independence.

There are other aspects to the film that complicate its relationship with the recent view of Kanak history. Using Legorjus's book as the source for his script, and casting himself in the lead role as Legorjus, allowed Kassowitz to produce an effective first person account of the crisis. It also assisted the narrative of the film switch from the site of the crisis to military bases where the political elements of the story could be further entwined with the hostage drama. However, it did relegate Kanak voices to more secondary roles. And while Kassowitz's film widens the story it can distance viewers from a purely Kanak first-person account of the conflict. The militant voice is, in an alternative way, mediated by a Eurocentric view of the conflict.

Tjibaou le pardon (Dagneau, 2006) seeks other goals in its attempt to tell the story of the aftermath of Jean-Marie Tjibaou's assassination. Essentially a Kanak-centred view of the present day stigma of the killing, which has its roots in Djubelly Wéa's individual response to the Ouvéa crisis, it situates itself in a territory where appeasement and apology are the dominant themes. These concepts are linked to Kanak customary ceremonies that then facilitate dialogue and reconciliation. Wéa's confrontational/paramilitary act is subsumed 
into a larger story that develops the story of the Wéa clan's reintegration into society. This involves a customary appeasement ceremony — 'le pardon' - which most of the Tjibaou clan accept. Its goals are clearly an attempt to reintegrate historical infractions into a cohesive and united view of the past, one that locates itself within the policies and ideals Jean-Marie Tjibaou negotiated and promoted during his political career.

It ends with a moving interview with Wéa's widow as she declares, tearfully, that Tjibaou's wife is 'now like a sister to me' (Dagneau, 2006). The strong feeling of unity which the film attempts to develop is supported by the voiceover commentary track through a narrator with a specifically Kanak accent. It is clear that Dagneau's intentions are to contextualise the events of the past within a specifically Kanak point of view. Underpinning much of the film is also the idea that mediation and dialogue are the best tools available to process a lived and collective trauma. In emphasising the importance of a customary approach to these issues the inference is that this is the only coherent way of proceeding. These ideas are echoed in most customary ceremonies (la coutume) around the territory, where exchanges of money and cloth cement dialogue and emphasise key values of respect and humility. Seen through this lens, the documentary is a reversioning and revisioning of history that includes the possibility of forgiveness and future unity. In this revisioning the radical voices of the past are bound to a clear idea of reconciliation.

\section{Radical responses to environmental crisis in Cap Bocage}

My own goals were much more modest when I began shooting Cap Bocage. My hope was that the film could provide a vehicle that would encourage dialogue in smaller Pacific communities who were examining their relationship with companies involved in extractive industries. I also hoped that the film would help audiences understand some of the benefits and dangers of occupying the firm environmental high ground if it ran at odds with the neoliberal agendas of mining companies. The recent history of indigenous environmental groups being captured and co-opted (Horowitz, 2014) by mining companies and impact and benefit agreements (IBAs) was also reason to present a more militant view of the debate. When the voices of protest are captured and co-opted, what is most often obscured is a clear truth: mining can never be a sustainable industry.

I would like to develop these ideas further by looking at two scenes from the film. Both scenes illustrate different aspects of militant opposition to the mine at Cap Bocage and both scenes also speak to some of the themes that I have developed above. The first involves a customary ceremony on top of the Cap Bocage mine. Echoing similar protests in the south at Goro, a group of people from $\mathrm{Ba} /$ Kaora and neighbouring tribes drive up to an area close to the landslide. They stage a small ceremony, placing a sacred totem pole as a warning to other Kanaks working on the mine. Once the totem pole is planted a clan leader begins a ceremony of apology to the ancestors for the damage done to the land by mining and neglect. This is followed by another small ceremony where a length of cloth is attached to a small pine tree.

118 PACIFIC JOURNALISM REVIEW 21(1) 2015 
On this journey up onto the mine we also encounter a digger (suspiciously burnt out) and follow the reactions of a variety of people from the tribe as they investigate the dramatic moonscape the mountaintop has become. Interviews edited into the beginning of the scene give the ceremony context. From my perspective, as director and editor, the film illustrates one of the key aspects I have had to consider when making documentary film: the balance between information and action.

The meaning of the ceremony is set up by interviews with clan leaders and others and these are intercut with images of the mine visit. They give context to a Kanak conception of ancestors (who manifest themselves in rocks and stones) and they situate the ceremony as not only one of appeasement but also one that can threaten: 'a curse will fall down onto anyone who tries to remove the totem,' one man tells us. But the background to this ceremony is complex. About a third of the clan leaders from Ba were in attendance, hardly a majority. The burnt out digger also clearly referenced a violent aspect to the protests.

A journalistic treatment of the scene would probably place the ceremony within a tighter rhetorical structure, one that concerned itself with the progression of facts and the investigation (Nichols, 2010). An academic work would better isolate the ceremony, tracking its lineage and the development of the dominant clans in the tribe. But both approaches, I believe, would also insulate us from both the beauty and the pathos of the scene itself, something that audiences have commented favourably upon during screenings. A journalist or current affairs television producer would also (most likely) have a tighter deadline or transmission date and, perhaps, a limited time to place the ceremony within the wider framework of the Cap Bocage protests. I had the luxury of a freer timeline and this was one of the first sequences I edited and brought back to New Caledonia to show people from the tribe and the wider area of Houailou. This helped give a variety of contexts to the footage. It allowed me to clearly identify the balance of the gathering with regards to clan leaders and also gave me specific information on some of the legends and spiritual importance of the site where the totem pole was planted.

Of equal importance was the fact that I could interpret acts of vandalism such as the burnt digger. This is played out quite ambiguously in this scene but later in the film we see Florent stressing to the gendarmes who come to his house that he was elsewhere. In fact, I was with him (and most of Mè Rhaari) in the south on the weekend the digger was set alight. Several independent sources also provided insights.

The petroglyphs that we see on rocks on the fringes of the mine are part of the cultural heritage of the site. This is one of the avenues of research I also followed and it involved understanding the Northern Province's identification and isolation of sites of cultural importance. The tree that is draped with fabric in the second ceremony also has a unique role in the Cap Bocage environment: it is endemic only to the specific $11 \mathrm{~km}$ peninsula on which the mine sits.

These matters of context are also tied to one crucial issue: how much do we need to explain and to what extent do the images, in isolation, allow audiences to read the 
scene? Understanding and balancing this intersection has been a key point in most of my previous work, but it was specifically important in this case where considerations of tribal legitimacy, culture, commercial interest, spirituality and colonialism were the main background elements of the story.

My final choice for the edit of this scene related to the 'voice' of the work that I was attempting to sustain during the film. As the shooting and editing evolved, it became clear these choices had to relate to Florent - the main subject. He is the protagonist and his actions catalysed the events of the story itself. The 'voice' of the film had to connect to his evolution as a character as the conflict unrolled.

However, there is another complication to understanding how events, actions and people are presented, and this relates directly to ideas of audience. The sum set of cultural understandings a New Zealand audience requires to interpret a scene such as this is vastly different from that of an audience in Houailou or Canala. The initial idea (and my preference) was to run the scene in the most direct manner possible, preferably as one continual observational sequence, dispensing with the cuts back to the clan leaders explaining the ceremony. We quickly realised that New Zealand audiences required context to understand the Kanak relationship between the present and the past, between current members of the tribe and their ancestors. Thus the beginning of this sequence needed edited interview segments that explained actions and gave the non-Kanak viewer context. This was a typical consideration that had to be faced in many of the scenes that we edited. Again, it was the balance between information and action.

The final scene I want to discuss concerns itself with an idea that many people talked about during my visits to the territory: the 'non dit', or the unsaid and unstated. The idea of the things that remain unvoiced, either to those outside one's clan/tribe or outside Kanak society itself, came up many times during my visits to the territory. The particular scene I want to refer to is a filmed conversation between Florent and two friends. The scene plays out after I ask Florent to explain the 'non dit' to me, and comment on the idea of New Caledonia being referred to as the 'le pays du non dit' (the country where things remain 'unspoken').

Florent expounds on this as it relates to his own freedom of speech. He explains he is free to say what he likes. 'Why?' he asks us. 'Because Ballande has total freedom here.' But this scene from the documentary is also undercut with other comments. Florent and his two friends, self-described 'bad boys of the tribe', also go further in explaining the idea of free speech. They tell the camera that there are limits to freedom of speech. ' $L a$ parole', the agreements and alliances that have been set down as the area has grown, cannot be reworked ('debougé'). And their ideas on respect and humility also reference a wider problem that disenfranchised young Kanaks face. Everything must happen 'with respect' they tell us. But then they recontexualise this as well. 'Even if you're an old prick ("vieux con") we'll still respect you.' 
While humour constantly undercuts ideas of freedom of speech and the constraints of going against les paroles (and even on my role as a 'stranger' who should 'go back to New Zealand after the job is finished'), this scene is not only an example of a style of filmmaking that runs parallel to a traditional investigative/journalistic model but also an example of the way militant voices are shaped and constrained within New Caledonian society.

It is also a scene that references the break down in relations between the tribe and the environmental association Mèe Rhaari. Gilbert Assawa, the chief of the tribe, highlights these tensions when he says: 'they started to take over the running of the tribe... nobody really knew.' The inference is that the militant actions of the association risked overturning the structure and stability of the tribe itself. It was my decision not to include sections in the documentary that would historically trace dominant clans and identify their roles in discussions with Ballande. A publication by historian Michel Naepels (2013) meticulously tracks the tribal structures of the area and unpicks the malevolent influence of colonialism on the administration of the area after its first contact with the French state (and missionaries).

Naepel's thesis asserts that the present-day structure of clans and tribes has been largely manipulated by French colonial authorities. This was done to such a degree that the less hierarchical traditional structure (many clans working together under the guidance of a more regional Grand Chef) was drastically subverted. The policing and administration of areas was devolved by French authorities to include specific and appointed tribal leaders (sub chiefs or petits chefs). Following this thesis he traces the clan conflicts that exist today and links them clearly to the drastic reworking of traditional structures of governance that balanced alliances and inter-clan relationships in pre-European times.

Naepel's ideas became the framework with which I interpreted this scene and other scenes. To trace the militant voice, the voices of opposition to the structures that were set up by the French administration, required analysis of Florent's place in the community. To disentangle this would require an expository framework, in turn steering the story away from what I saw as the key idea: voicing the 'non-dit' through a central character. The consequences of Florent's challenge to authorities (both the structure of the tribe and the legitimacy of the mining company's mining permit) are directly played out in the final scenes of the film. In this sense the consequences of Florent's challenge are tangible.

As a filmmaker concerned with creating a personal portrait, this scene also serves to give specific weight to personal conversations. In this way, the timeline of the crisis, the clean-up and the judicial zigzags serve a purpose beyond framing a David and Goliath battle. In fact, we tried very hard to subvert the giant-fighting mythological story structure. In veering towards the personal, and relegating the importance of an omniscient view of the conflict, the film's intention is to engage audiences in another, more subtle, conflict concerned with human and cultural dynamics. Stella Bruzzi talks about the intersection of many of these varieties of truth in documentary when she states that a 'documentary 
is itself the crucial point at which the factual event, the difficulties of representation and the act of watching a documentary, are resolved' (Bruzzi, p. 9). In the case of Cap Bocage, this act of 'resolution' is still being explored and will be surveyed in further research after the film begins its 'run' in New Caledonia in October 2015. It is here where I will discover if some of the decisions to give weight to the personal, rather than a wider view of the conflict, connect an audience more closely to the validity of the militant voice and the undercurrents belonging to unstated assumptions and the 'non dit'.

\section{Neo-liberal strategies and the future of nickel}

I wish to conclude with some comments on current negotiations between mining companies and Kanak communities. At the time of writing (August, 2015), the territory has been paralysed for the last 20 days by a strike led by the truck drivers' union. Their demands centre around challenging a policy restricting some of the exports of nickel ore to countries like China. Their demands go directly against a careful policy developed by industry and government that seeks to control the way nickel is processed and exported ('La Nouvelle-Calédonie paralysée', 2015). The strikes and roadblocks signal two ideas that I have discussed. The first concerns the tendencies towards militant reactions, which I have mentioned in relation to environmental protest. The strike, in many ways, is an indicator of the volatility of relationships between miners, workers and the government.

The second is anchored to an idea that both Caldoche loyalists and FLNKS leaders see as a cornerstone of the territory's development: the continued and accelerated exploitation of nickel as the stimulus to building either a new Kanaky (for the FLNKS) or a modernised New Caledonia under a French umbrella (in the case of loyalists). There are levels of complication to this strike. One of the main issues centres on the territory's plan to control the market for unprocessed nickel ore. Smaller mining companies (such as Ballande) have been forced to search for markets in China, going against the wider strategy set down for the territory. Thus assuming a militant anti-mining position isolates environmental protest from a complicated mosaic of voices at both union level and across a wide range of varied nickel mining interests. All of these voices are lobbying, in their own way, for the acceleration of nickel exploitation and production. In my opinion, this makes the articulation of the anti-mining point of view even more important.

The question remaining for many who live in the territory is: can the future of the territory be economically viable without mining? Last year I walked through the extensive planting surrounding Do Neva High School. There the emphasis is on training young people how to farm sustainably and how to develop markets for targeted crops, such as organic coffee and food crops. The director of the school specialises in teaching organic farming and the idea of permaculture. He discussed the pull of the mines for young people and catalogued the markets he has developed for crops like organic coffee: markets where supply considerably outstrips demand. According to his calculations, the careful

122 PACIFIC JOURNALISM REVIEW 21(1) 2015 
tending of crops on a family plot for four hours a day will generate more income for the worker than a day on the mine. This is one version of a future for Kanaky and it is one that is often ignored by those pushing mining agendas.

La Rapport Cyclop 2015, a resumé of natural resources and global markets written by academics in France, also comments on the long-term prospects of nickel as a pathway to development. In an interview, Professor Philippe Chalmin, co-author of the study, is scathing about this. He compares New Caledonia's dependence on nickel to a doped cyclist on the Tour de France. When his performance-enhancing drug is no longer available the cyclist stays hooked ('accroc'). 'It's not a source of economic development,' he says 'but rather it anchors the country's producers in a state of dependence' [my translation] (Jeannin, 2015).

The other key factor in discussing the relationships between mining companies and indigenous peoples is the complex dialogue that begins between all parties once an application is underway for a mining permit. At the time of writing, Ballande has received permission from the tribe to mine other areas of the Cap Bocage peninsula. Almost all of the tribe have agreed to this and most say that their relationship with the miner (and the management of the mine) has improved dramatically since the landslide in 2008. In further research work I hope to cover some of these issues, but the process of seeking and receiving approval to mine is also evolving. Research developed by Horowitz (2014) examines the way power structures shift once indigenous peoples begin to engage with the IBAs mining companies are now obliged to present to them. She sees this as part of a new neoliberal way of engaging with populations, one that can co-opt, capture and delegitimise voices of protest.

My portrait of Florent is intricately founded in my own personal approach to storytelling and to the 'voice' of the film that I am attempting to maintain. But this is also a film addressing an aspect of protest that can be easily sidelined in the rush for economic development and independence. The film was made with the modest hope that it could further dialogue and articulate a current of radical thought and discussion. The militant environmental ideas that Florent expresses are vital to include, and to consider, as Kanaky weighs up its future and reconciles itself with the events of its past.

\section{References}

Bruzzi, S. (2000). New documentary: a critical introduction. London, UK: Routledge.

Dagneau, G. (Director). Dagneau, G \& Kotra, W. (Writers). (2006). Tjibaou le pardon. [Motion Picture]. New Caledonia: aaa, ADCK Centre Tjibaou, RFO.

Deransart, T. (Writer). (2011). Le Figaro. Ouvéa: les mensonges de Kassovitz. Retrieved on August 29, 2015, from www.lefigaro.fr/cinema/2011/11/12/03002-20111112ARTFIG00287-ouvea-lesmensonges-de-kassovitz.php

France 2. (1988). Jacques Chirac \& Francois Mitterand face à face. Retrieved from:https://www. youtube.com/watch? $\mathrm{v}=6$ EsitMtqq0I 


\section{DOCUMENTARY PRACTICE IN THE ASIA-PACIFIC}

Gooch, N. (2015). Making the case for a political ecology investigation at Goro nickel mine. Pacific Journalism Review, 21(1), 164-176.

Horowitz, L. (2008). 'It's up to the clan to protect': cultural heritage and the micropolitical ecology of conservation in New Caledonia. The Social Science Journal, 45, 258-278 doi: 10.1016/j. socscij.2008.03.005

Horowitz, L. (2014). Culturally articulated neoliberalisation: corporate social responsibility and the capture of indigenous legitimacy in New Caledonia. Transactions of the Institute of British Geographers, 40: 88-110. doi: 10.111/tran.12057

Jeannin, J. (2015). 'La Nouvelle Caledonie n'est plus vraiment importante pour le marché du nickel,' estime Philippe Chalmin. 1 er Outre Mer. Retrieved on August 29, 2015, from http://m.la1 ere.fr/2015/05/21/la-nouvelle-caledonie-n-est-plus-vraiment-importante-pour-lemarche-du-nickel-estime-philippe-chalmin-257839.html

Kassowitz, M. (Director). Kassowitz, M \& Rossignon, C. (Producers). (2011). Rebellion [Motion Picture]. France: MNP Enterprise \& Nord-Ouest Productions.

La Nouvelle-Calédonie paralysée par un conflit sur l'exportation de nickel (2015, August 21). Le Monde. Retrieved on August 29, 2015, from www.lemonde.fr/economie/article/2015/08/21/ la-nouvelle-caledonie-paralysee-par-un-conflit-sur-l-exportation-de-nickel_4732961_3234.html

Legorjus, P. (1990). La Marale et 'action. Paris, France: Fixot

Le Meur, P-Y, Horowitz, L \& Mennesson, T. (2013). 'Horizontal' and 'vertical' diffusion: the cumulative influence of impact and benefit agreements (IBAs) on mining policy -production in New Caledonia. Resources Policy, 38(4), 648-656. doi:10.1016/j.resourpol.2013.02.004

Marbrook, J. (Producer \& Director). (2003). Dark Horse [Documentary]. New Zealand: Dark Horse Pictures.

Marbrook, J. (Producer \& Director). (2012). Mental Notes [Documentary]. New Zealand: vfilms $\&$ NZFC.

Naepels, M. (2013). Conjurer la guerre. Paris: Editions de L'École des hautes Études en science social.

Nichols, B. (2010). Introduction to documentary (2nd Ed). Bloomington, IND: Indiana University Press.

Jim Marbrook is a filmmaker and a lecturer in Television and Screen Production in the School of Communication Studies at AUT. His films include the award-winning documentary Dark Horse (2003) and the multi-award winning 2014 feature film The Dark Horse (co-producer), which was inspired by the original documentary. His other films include the critically acclaimed Mental Notes (2012), Ko Whanganui te Awa (2006) and the award-winning short film Jumbo (1998). His latest documentary Cap Bocage (2014) was nominated for three NZ Film Awards in 2014 and received early assistance from the Pacific Media Centre. He is one of the founders of Te Ara Motuhenga-a new AUT research group focused on documentary practice.

jmarbroo@aut.ac.nz 